Stalcup, Meg. 2013. "Interpol and the Emergence of Global Policing." In Policing and

Contemporary Governance: The Anthropology of Police in Practice. ed. William Garriott, 231- 26 I.

New York: Palgrave MacMillan.

Reproduced with permission of Palgrave Macmillan.

This extract is taken from the author's original manuscript and has not been edited. The definitive version of this piece may be found in Policing and Contemporary Governance edited by William Garriott, which can be purchased from http://www.palgrave.com.

9

\title{
Interpol and the Emergence of Global Policing
}

\author{
Meg Stalcup
}

\section{Introduction}

"The New Interpol is not simply a collection of databases and communication networks," said Secretary General Ronald K. Noble to national representatives at Interpol's 2002 annual assembly. "You have heard me use the expression-the Interpol police family. It is an expression that we wish to turn into reality" (Noble 2002). The organization, dedicated to police cooperation, had previously taken four to six months to transmit even high-profile requests for arrest between member nations. Notices were sent as photocopies, mailed by the cheapest and lowest priority postage available (ibid.). ${ }^{2}$ Modernization and reorganization, however, had just cut the time for priority notices to a single day. The Secretary General's call for "police family" named the organization's ambition to create fellowship through these exchanges.

Interpol is not a police force. Neither national nor international laws are enforced by Interpol directly, nor do staff and seconded police officers working under its name make a state's claim to the right of physical coercion (vide Weber), or to powers of investigation and arrest. Policing, however, depends on vast numbers of people - "media liaison offices, environmental scanning units, quality assurance teams, community involvement teams, criminal intelligence specialists"-who spend their time on "knowledge work" (Sheptycki 1998, 59). Much of policing consists of "processing and exchanging knowledge about crime and insecurity" (ibid.); at Interpol, knowledge work is the primary activity.

A measure of contemporary life is assimilated and translated into 
police information: personal documents, bodies, records of international travel, court decisions, cyber consumption. Enabled by data technology, Interpol increasingly has been able to find and fill niches in the complicated apparatus of global police cooperation, which is partly, but not wholly, international. ${ }^{3}$ Operating in relation to sovereign nations and their many law enforcement agencies, as well as transnational corporations, nongovernmental movements, the United Nations and the Group of Eight, criminal networks, and other shapers of security and insecurity today, "global" does not mean everywhere, but anywhere within those relations. Interpol tries to produce a shared policing ethos through meetings, conferences, and train-the-trainer initiatives, but the delimiting feature of global policing is not an occupational "culture" of police, bureaucratic autonomy, or the emergence of a new transnational police subculture. Rather, global policing develops out of a distinct blend of legal tools, justifications based on shared needs and goals, and concerted cooperation within a human and technological assemblage. These elements shape flows of information and expertise. Standard procedures change, and new practices are made possible. Regulated by multilateral and bilateral agreements, personal and political bonds are created with Interpol, and between law enforcement in different countries. Interpol's primary services concern information. Among the most used are storing and providing access to nominal data for known international criminals, missing persons, unidentified bodies, and stolen identity documents; and its system of notices.

Global policing at Interpol came about not through a happenstance of technology and history, but by a designed, narrow orientation to function that let it escape much of the friction that beset such institutions as the United Nations (Russell 1965). Interpol uses the existing laws within countries, even where diplomatic relations do not exist between them, in order to operate "as though" understandings of crime and the designation of criminals were universal (INTERPOL 1956, Art. 2). Of course they are not, as requests for political asylum, the designation of terrorist organizations, espionage, and drone killings, among other examples, make evident. "[L]ittle difficulty is encountered in the mere statement of the rights," wrote Richard Mckeon (1948b, 180), an advisor on the draft- ing of the Universal Declaration of Human Rights, which Interpol adapted into its constitution in 1956. "The differences are found rather in what is meant by these rights" (ibid.). McKeon pointed to two paths for dealing with the problem of differences: actual philosophic agreement, or that failing, as historically it has, "a political frame may be sought within which agreement is possible concerning common action toward common ends" (ibid., 181). Interpol operates without attempting to establish explicit consensus on the philosophic base of its actions, instead getting 
participants to agree to regulations and accompanying practices.

In this chapter I show how global policing has found ways of acting through the vast array of law and law enforcement mechanisms around the world, in a noteworthy experiment in developing a frame for common action. Predominantly through Interpol's role in the circulation of information, it enters into relationships in which all parties are inflected and shaped. In the process, it has helped to transform the "flexible security apparatus" (Noble 2009) $)^{4}$ of police cooperation, and hence aspects of governance, from the local to national, regional, and global. The chapter draws on time spent as an intern at the General Secretariat, as well as Interpol publications, news stories, and interviews with staff, to discuss its history, institutional structure, and daily practices. Three cases are presented, dealing with Red Notices, national sovereignty, and terrorism, through which I explore some of the problems arising in Interpol's political and technical operating arrangements. In conclusion I compare international and global policing schematically and examine Interpol's attempts to give institutional and procedural direction to its still-evolving form of policing.

\section{April 2007, Lyon, France}

My attendance at one of Interpol's big annual meetings was a fluke. Throughout the spring of 2007, the bioterrorism program at Interpol, where I was an intern, had been trying to get member countries to respond to a questionnaire about the status of their domestic legislation on bioterrorism. In April, representatives from each member's National Central Bureau (NCB) gathered at the General Secretariat in Lyon, France, to hear updates and proposals about routine governance. The "Heads of NCBs" meeting, of which this was the third, was also an opportunity to socialize in an informal manner, in order to establish personal bonds and create networks.

The return rate on the bioterrorism questionnaire had been dismally low, and in a last-ditch effort, the coordinator of the program decided to have his assistants distribute paper copies at the meeting and then stand around smiling to collect them. The secretary, a program assistant, and I were given security passes, which were required even though we worked at the headquarters, and together we trucked over to the conference auditorium, located at the other end of the tidily landscaped stretch of modern buildings called the Cité Internationale. We arrived just before our boss was scheduled to give his 15-minute presentation to the massive assembly. However, as it turned out, the meeting was running two hours late, and so we settled in to watch the presentations, already in progress.

The meeting's overly dramatic security - such as the need for us to 
have passes-was typical of Interpol. Nothing would happen or be revealed that required the meeting to be closed to the press, let alone to already vet- ted employees. The representatives engaged in posturing that emphasized their putatively equal status, but that would be familiar to anyone who has watched proceedings at the United Nations. Conspicuously polite salutations were followed by a business-like approach to checking off agenda items. The only surprise might be the directness of interactions. At one point someone's retirement was announced, and from the middle of the audience of Interpol heads from around the world came the request that, before the retiree departed for good, a query to the stolen vehicles database be fast-tracked. Seeming out of scale in the giant auditorium, the request unsubtly made the point to all in attendance that the query had not yet been answered.

At this sort of meeting, secret information or the details of operations would never be discussed, since revealing such things would be a security breach if heard by other national representatives at the assembly, as much as if heard by the press or other attendees, such as myself. But Interpol uses its mystique and a certain dose of ostentatious security as a tool of publicity, an argument to the effect that it holds secrets and therefore must be important. When the organization moved from Paris to Lyon in 1989, it built new shiny headquarters in the shape of a fortress with a moat, a façade for the mundane French bureaucracy inside. A moat is not a discrete way to ensure security; it rather draws attention to the need for security, which was real enough given that the move from Paris came after a 1986 terrorist attack on the organization. The moat was subsequently drained (it turned out to attract mosquitoes) and the everyday business of Interpol is staid. The decorum is to be expected, given that no one is put to the adrenaline- pumping test of frontline law enforcement, and half the staff are in fact lawyers. The discrepancy between day-to-day work and the stirring press releases on Interpol's website fed a rumor among employees of five secret underground levels, staffed round the clock with furiously typing liaisons who are piped espresso and hot meals from the other side of the Rhone.

As we settled into the meeting, I fiddled with the headphones that provided simultaneous translation in Interpol's four official languages, English, French, Spanish, and Arabic. The pair I had didn't work, and I went back to get a second, and then clicked through the channels, on all of which a female voice moved smoothly in unison with the voices coming over the auditorium loudspeakers. Secretary General Noble, a lawyer and former Undersecretary for Enforcement in the US Treasury Department, and Jean-Michel Louboutin, the Executive Director of Police Services, formerly with the French National Police, were seated at a table on the stage, assisted by a subdirectorate head. The lighting on the platform, 
bottom-center, was dramatic, leaving in relative darkness the upwardsweeping seats filled with career cops from 187 members. (By 2012, the number had increased to 190, out of the world's 195 nations. North Korea and Taiwan are among the few nonparticipants). As one speaker after another presented at the podium, a live feed of the proceedings was projected on a giant screen hung above the stage.

\section{Interpol's Legal Status}

The historical development of law enforcement cooperation has been ably documented; ${ }^{5}$ some elements of that history are central to the evolution of Interpol's legal status, and to debates over global "policing." Heads of state and security in Europe were first swayed by the Revolutions of 1848 to strengthen and professionalize policing practices. Uniformed police brigades were stationed in principal cities in order to be able to deal with riots and insurrections (Liang 1992, 10), leading to what Silver (2005) called "policed societies," in which the police were organized to flexibly respond to crime-or political agitators - on an asneeded basis. After the revolutions, European governments increasingly agreed that they needed to coordinate their efforts against political dissenters (Jensen 2004). They were influenced in part by widespread fears of a vast anarchist- terrorist conspiracy, although those who committed the acts of violence were often unaffiliated with the formal anarchism movements. The 1890s came to be called the "Decade of Regicide" (ibid.), as self-described or alleged anarchists successfully assassinated presidents, prime ministers, and monarchs. Perhaps as influential, however, were "dynamitings," both threatened and enacted, which were widely publicized by the then-new mass media, and spread the impression that "violence previously reserved for soldiers, policemen and unpopular politicians" was being visited upon common citizens (Jensen 1981). In this situation, the "high police" charged with policing political activities (Brodeur 1983) and the "low" or "order" police of common crimes (Liang 1992) concurred that cross-border threats were grave. Their united voices were persuasive in organizing support for international police cooperation, despite tensions between the European governments on other issues (Jensen 1981).

The first International Criminal Congress in 1914 was convened by Dr. Johann Schober, head of the Vienna police, and Prince Albert of Monaco. The range of mechanized travel was increasing, and with it, escapes from justice. The conveners hoped to organize international police cooperation for criminal matters such as extradition. The lack of a procedure had been highlighted the year before when the perpetrator of the high-profile theft of Austria's imperial jewels was found and detained, but 
there was no legal process available for getting the jewels, and the thief, back to Vienna (Gerspacher 2008, 174). The 1914 Congress created a draft agreement for cross-border police cooperation, but efforts to get it signed were interrupted by World War I. Interpol was officially founded after the war, in 1923, using the text of the earlier draft, with a mandate to sup- port and assist "all organizations, authorities and services whose mission is to prevent or combat international crime" (Interpol 2010c). During World War II the Nazis co-opted the organization. At the end of that war, Interpol reformed, moved headquarters to France, and in 1956 passed a new constitution binding itself in spirit, although not yet an any practical or technocratic fashion, to the heady goals of the Universal Declaration of Human Rights.

Interpol was plagued for many years by accusations of illegitimacy because it was not founded on the basis of an international treaty. ${ }^{6}$ When the organization declared itself into existence in 1923, the voting had been done by law enforcement delegates from 20 countries rather than diplomatic representatives explicitly endowed with the powers of negotiation (Naím and Kendall 2001). Interpol backdoored itself into recognition by persuading the League of Nation to name it as the official "agency of fulfillment" for the 1929 Convention on Currency Counterfeiting, an arena in which Interpol had considerable expertise (Fooner 1989, 52). Getting named in a supra-national, international document "amounted to a de facto recognition by the highest international political authority at that time" (ibid.). Several subsequent European conventions strength- ened this claim to legitimacy by including a provision that required using "Interpol's organization for specific elements of their mandates" (ibid.). Interpol applied to the UN for the status of Non-Governmental Organization, which was granted in 1948, and then in 1971 it made a special arrangement with the UN to be treated as if it were an Intergovernmental Organization, a higher status category than Non-Governmental Organization. This was described by one prominent international lawyer as "in effect, a treaty between the two organizations" (Sheptycki 2004, 120).

Interpol was hounded by detractors over the following decades. Much of its struggle can be traced to a smear campaign by the Church of Scientology. Church founder and then-leader Ron Hubbard was conducting business from his yacht on the high seas in order to avoid national legal and tax jurisdictions, leading multiple countries that were investigating the church for fraud as early as 1957 to ask for assistance from Interpol (Fooner 1989, 12-15). By the 1970s, Scientologists were retaliating with a surveil- lance, investigation, and negative publicity crusade to discredit and impede the policing organization. The fallout from their attacks included lengthy United States congressional inquiries and lawsuits, as well as a pervasive public legacy of, if not disrepute, at 
least distrust.

In a less aggressive although persistent manner, academics have questioned if Interpol's originary agreement, between representatives who seemingly were not endowed with the power to sign treaties, is legitimate. International seems to suggest diplomatic agreements between nations, which goes some way to explaining why Interpol has been viewed as suspect, and lends a certain irony to its name (ICPO-INTERPOL, where the official abbreviation "ICPO" stands for International Criminal Police Organization). A law scholar who led the Office of Legal Affairs at Interpol, Rutsel Martha, has argued that the question of Interpol's legitimacy properly comes down to "how to establish whether the consensus of wills reflected in Interpol's Constitution can be attributed to the countries of those officers who participated in its adoption and continue to participate in its activities" $(2010,151)$. Precedent exists, he argues, for "even the procès-verbal of an international conference [to] form an adequate record of an informal agreement" (ibid., 150-151). Several factors, he suggests, indicate that Interpol's representatives did represent the will of their countries, both at the 1923 founding and in 1956 when the new Constitution was created, and this is annually reconfirmed by statutory contributions. ${ }^{7}$ Signatures authorizing attendance were provided by national secretaries and ministers whose responsibilities included international law enforcement cooperation (ibid., 164). New membership in Interpol must be submitted to and approved by the appropriate governmental authority.

Member states in the United Nations have an obligation to register treaties and international agreements with the UN Secretariat, which in turn is mandated to publish them. The Secretariat examines each instrument to "satisfy itself that it, prima facie, constitutes a treaty between entities possessing treaty-making capacity, and, whatever its form, imposes on the parties legal obligations binding under international law" (Michel 2011). In March of 2008, Martha, acting as the General Counsel in Interpol's Office of Legal Affairs, wrote to the United Nations to request a ruling on whether Interpol's Constitution qualified for registration and publication. After review, the Under-Secretary for Legal Affairs of the UN, Nicholas Michel, noted that whether the Constitution had been intended as a formal treaty was less relevant than the character it had acquired over the years, and that there was no doubt that Interpol was today recognized as an international organization (Michel 2011). Following Michel's suggestion, at Interpol's 2011 General Assembly representatives adopted a resolution agreeing that Interpol's constitution should be considered an international agreement (a treaty), and voted in favor of submitting the Constitution for publication by the United Nations (INTERPOL 2011). Publication would enter Interpol's constitution into 
the permanent UN record as a treaty, and provide the highest level of legal confirmation available that it is an intergovernmental organization. ${ }^{8}$

\section{The Global Form of Policing}

Given the state-centric connotations of "international," transnational policing has been the preferred term among scholars for sub-state or even more micro-level cross-border law enforcement. Transnationalization, according to Sheptycki, "attempts to understand action on the global stage by reference to state action as it is conditioned by non-state factors and processes in world politics" (Sheptycki 2000, 6). Sheptycki criticizes globalization discourses that characterize "the newly emergent world order as one where states have been disempowered and wholly subordinated to the power of transnational capital" (ibid.). Indeed, "globalization" has been posited as the decline of the state or as Bruce Kapferer notes, there is "a tendency to oppose globalization to the state rather than concentrating on the new state formations that are emerging within globalizing processes and, indeed, are integral to it" $(2005,287)$. An alternative understanding of globalization is needed to make sense of both old and new relationships, events, and processes.

Collier and Ong describe globalization through the range of phenomena that present its changes, and suggest that there are "global forms" to be found. These phenomena can be abstracted from the particular situations in which they manifest, without that abstraction requiring or suggesting a more general theory about globalization. They are "limited or delimited by specific technical infrastructures, administrative apparatuses, or value regimes, not by the vagaries of a social or cultural field" (Collier and Ong 2004, 11). As global forms articulate in specific situations, or "territorialize" to become assemblages, they are able "to assimilate themselves to new environments, to code heterogeneous contexts and objects in terms that are amenable to control and valuation" and to "define new material, collective, and discursive relationships" (ibid., 4). Transnational police cooperation is constituted by security actors drawn from public and private, local and national, and identifiable-although still mutable-legal, technological, and political elements. If some police actions are understood to occur through the relationships between these actors and elements, the question can then be raised as to which should be properly considered "global."

Valverde and Mopas emphasize "the persistently, unfashionably nonglobal character of much policing, even of supposedly international policing" $(2004,236)$. "[T]he number of international covenants or agreements conferring international powers on police is exactly zero," they remind readers, and for multiple reasons, "States and local municipalities remain 
the key venues for, and jurisdictions of, law enforcement" (ibid.). They conclude that Interpol is therefore "a fancy 'policeman's club" " (ibid., 248) for professional contacts or an organization, "comparable to international organizations of academics" (ibid., 236). Friendly sociality was not the whole story even in the past though, and the Secretary General's aspira- tional appeal for police family suggests that it has not manifested fulsomely either. More germanely, Interpol was not designed to act as a scaled-up version of local policing. Interpol has changed and assimilated itself into heterogeneous contexts of action, from partnerships with International Criminal Tribunals and an array of United Nations entities, to direct access by border control, thus connecting and shaping such practices as well as creating new kinds of venues.

Bowling and Sheptycki, quite differently, emphasize universality. They define global policing as "the capacity to use coercive and surveillant powers around the world in ways that pass right through national boundaries unaffected by them" $(2012,8)$. Yet no matter how powerfully those capac- ities enable traditional police activities such as surveillance, detention, and arrest, the political and socio-cultural milieus within which the acts are carried out produce differentiation and impart limits. The technical infrastructure and administrative apparatus provided by such organizations as Interpol are not passively received, but actively adapted to local practice within specific legal regimes.

Interpol's innovations in services to member nations, related to compiling data and making that data accessible, are taken up and put to use in different ways. Face-to-face contact between officers, groups with a specialized crime focus, regional encounters, and materials spreading "best practices" are productive not because they foster a new subculture of transnational police, or because they displace national sovereignty (they may in fact advance its exercise), but because they create relationships and flows of information that were not there before. The adaptation of these technological and human capacities into specific, local forms of actions are what can be considered the "global" part of policing.

\section{Global Policing at Interpol}

Where the technology is in place, frontline officers can access Interpol's databases from their patrol cars, as well as at airports and borders. How- ever, in much of the world, the cooperation Interpol facilitates is between officers at the National Central Bureaus and the General Secretariat; or between officers and non-law enforcement working on a shared topic, such as counterfeiting. Notably, Interpol itself is acting as an interface. Gerspacher observes that in the 1990s, national governments became increasingly fond of the idea of international police 
cooperation, while police at the local level resisted forming partnerships with unknown col- leagues across borders $(2008,180)$. The effect of Interpol's structure in terms of user experience is therefore, appropriately, that Interpol is not merely the intermediary; rather, Interpol is the direct partner, and nations depositing information are one step removed from each other. Countries will only enter and use information when a degree of trust exists, if not in each other, at least in the safeguards on data sharing and processes of verification. This system means that the relationship is formed, most immediately, with Interpol.

Making professional contacts, however, is a benefit for those "seconded" to headquarters. The Director of Specialized Crime when I was there, a career Royal Canadian Mounted Police officer, told me, "one of the challenges of Interpol is to work with people from so many cultures, but if they get one thing from this, it might be the human connections. My deputy was a guy from India who will now go and be the Inspector General of India, which means all the cops in India will answer to him. And in the future when I need something, I can call up and say, 'hey, remember when you were here? And by the way, I need this and this done.' So people volunteer for this assignment, and if they want to really use it well, they go home with a pocketful of business cards." The emphasis on establishing contacts seemed to be partly because the opportunities for other benefits, such as developing new areas of expertise, were greatly diminished by the structure of seconding. Many police officers pass through Interpol on a three-year assignment. They are uprooted, often with their families, and need a period to readjust, as well as settle into new duties that often have nothing to do with their expertise back home. A manager told me he considered himself lucky to get six solid months of work from those he supervised in the middle of their stints. Therefore, the relationships formed may constitute a more substantive legacy of the experience than participating in the global circulation of police information, although the latter may consume the bulk of officer time.

The various technologies of information sharing are what create institutional bridges, however. Interpol's Stolen \& Lost Travel Document database holds reports of missing passports, which it is in the process of being made widely available in real-time to border officials. When Qatar's NCB Doha integrated the database into its immigration checkpoints, so that line officers could check entering individuals, their queries totaled 7.5 million in the first year (INTERPOL 2010b). Other databases include Stolen Works of Art, Fingerprints, DNA Profiles, one for ballistics data, and, as mentioned by the questioner in the annual meeting, Stolen Motor Vehicles.

Interpol's color-coded Notices, which it began emitting in 1946, are 
its best known information sharing service. They transmit data such as a missing or discovered person (yellow), a warning about someone's criminal activities (green); or even a modus operandi (purple). Legally, the General Secretariat issues these notices, but in practice, they are put online as temporary publications by a National Central Bureau, as well as option- ally to the public, and then reviewed by the General Secretariat's Office of Legal Affairs (Interpol 2012a, 31). A "diffusion" is similar in content but legally different; it is published by a National Central Bureau, and can be sent exclusively to one or more Bureau without informing the General Secretariat. The use of both types of missives dramatically increased with the introduction of the online I-Link system. At the end of 2011, there were 40,886 active Notices in circulation, and 48,310 Diffusions (Interpol 2012b).

The best-known advisory is the Red Notices, which constitute what the press often calls, simplistically, an international "most wanted" list. Red Notices request the detention or arrest of an individual for extraditable offenses. Personal identifiers and judicial data must be supplied by the justice system of a member nation, or an international entity with appropriate powers. By acting as each other's proxies, nations functionally extend warrants across borders, although detention, arrest, and, separately, extradition, are subject to review by the country in which the wanted individual is located. The process is also subject to any bilateral agreements that exist between a requestor country and a receiving country.

As we waited at the "heads of NCBs" meeting in April of 2007, Martin Cox, the Assistant Director of Interpol's Fugitive Investigative Support unit, gave a presentation on fugitive investigations, and the problems and challenges of Notices. Notices and diffusions can be more controversial than they might seem at first glance-who doesn't want missing persons found or criminals caught and impeded from harming others? But "crimes" may be part of political protest, thus outside of Interpol's purview and protected in most countries. Although a crime may meet the standard of double or dual criminality, i.e. it is a crime in both countries, the charges in a notice may be trumped-up. There are, in fact, well-documented cases in which Notices have been abused to persecute political refugees (Johnston 2012). ${ }^{9}$ In sum, a Notice can constitute an attempt to use the Interpol system to deprive someone of liberty, when that person actually needs protection (Lewis 2011).

Cox discussed with the assembly less grave, but probably more pervasive, problems. Many of the difficulties that National Central Bureaus have with notices, he told the assembly, are simply administrative. Notice forms are sometimes filled out incorrectly. Other times, they are correct but incomplete. Many bureaus lack expertise in how to use the 
notices, he said, or have translation problems. Another issue is what he described as a huge imbalance between countries in the number of requests submitted; essentially there are countries that use notices and countries that do not.

After Cox's presentation, a lively debate ensued, in which it became evident that nuances of the procedures for notices were unclear. Portugal argued that there was no real difference between a "diffusion" and a Red Notice. "The information is the same," said the Portuguese representative. Noble corrected him, saying that there was a huge difference: any country can issue a diffusion of information to whomever it wants, without requirements or restrictions on language or format, whereas the General Secretariat must review notices. However, the ability of Interpol do this vetting, which as recently as 2008 was a point of pride, has been compromised by the massive increase in notices that came with the introduction of the I-Link system. Members are required to ensure that data they submit complies with the rules, and an advisory group subsequently checks their validity, although not their accuracy (Cheah 2012, 385-87).

The representative from Senegal asked, "is a member country allowed to oppose the issuance of a Red Notice?" Cox answered, "yes, the legal office does a review and may try to bring the countries into agreement, but also no, the country won't necessarily be informed." Secretary General Noble added, "It is our presumption that a country requesting a Red Notice is acting in accord with Interpol policy," although as the next section shows, philosophic divergences may "lead to differences and difficulties in interpretation" (McKeon 1990, 49).

\section{"Wanted by Interpol"}

Somewhat awkwardly for Interpol, in August 2009 Iranian president Mahmoud Ahmadinejad nominated General Ahmad Vahidi for the position of Minister of Defense (BBC News 2009). Ahmadinejad had recently been at the center of world news after violently suppressing protests over his election, and the general was doubly useful to him. One, Vahidi had long been in the employ of Iranian defense. Two, his antiimperialist credentials were enhanced by being on Interpol's Red Notice "wanted list," - Argentina having issued a warrant for his arrest that was circulated to law enforcement around the globe (ibid.). Vahidi had come to be the subject of a Red Notice through neither carelessness nor lack of over- sight on Interpol's part; his was one the few cases to go all the way through Interpol's dispute resolution process in order to be placed on that list.

In 2003, the Argentine National Central Bureau in Buenos Aires 
requested that red notices be circulated for 12 individuals, some of whom were Iranian government officials (INTERPOL 2007a). The Iranian Bureau in Tehran promptly disputed the request. The wanted men were accused of directing Hezbollah to carry out a 1994 bombing in Buenos Aires, which had destroyed the seven-floor Israeli-Argentine Mutual Association (AMIA), killing 85 people and injuring around 300 more (BBC News 2006). Described as one of the most deadly attacks on Jews since World

War II, investigation into the incident was plagued by corruption on the part of Argentine authorities. The improprieties were systemic and, eventually, well documented. One video showed the investigating judge offering $\$ 400,000$ to a key witness. The judge countered that it was for the witness to protect himself, because he had admitted complicity and implicated others (Abiad 2006). In 2009, charges would be brought against former Argentine president Carlos Menem, his brother, the judge, and multiple other officials for obstructing the investigation and protecting suspects (Sullivan 2010). With so many instances of misconduct, Iran had solid grounds for its objections to the Red Notices for its nationals.

Indeed, the first Iranian challenge was upheld. In accordance with Interpol's procedures, the Executive Committee was asked to evaluate the conflict between the Buenos Aires and Tehran Bureaus, and they rejected the Red Notices in light of an Argentine court's own conclusion that investigating Judge Juan José Galeano had committed "substantial violations of the rules of due process" and "irregular and illegal actions" (INTERPOL 2005). NCB Buenos Aires appealed, but in a 2005 vote, the 74th General Assembly "overwhelmingly endorsed the Executive Committee's decision to cancel the Red Notices" (ibid.). The Executive Committee advised that for a notice to be issued, new warrants by a different judge would be necessary. In Argentina, alongside the investigation into irregularities, further investigation and sifting of information about the attack took place.

Ahmad Vahidi at the time of the AMIA bombing was the head of alQuds, a special forces branch of the Iranian Defense that operates abroad. Through a combination of testimony, documentation of cell phone calls from the Brazil-Paraguay-Argentina tri-border area, country entries, and bank account records, evidence was brought together to allege that Vahidi had participated in and approved of the decision to attack AMIA during a meeting on August 14, 1993, and that other Iranian government officials, as well as Hezbollah members, had been involved (Sturcke 2009).

This was not, to be clear, an investigation by Interpol but by Argentine authorities. Warrants for Ahmad Vahidi, former president Hashemi Rafsanjani, six other Iranians, and one Lebanese national were 
issued by an Argentine judge in November 2006 (Berri 2006). Interpol's Office of Legal Affairs approved six of the nine requested notices (INTERPOL 2007a). National Central Bureau Tehran challenged the requests on the grounds that the warrants were "politically motivated" and based on "unfounded and undocumented charges" (Noble 2007). After reviewing written sub- missions and oral presentations from both countries' NCBs, the Executive Committee upheld the recommendation of the Office of Legal Affairs (INTERPOL 2007a). Iran maintained its objections. Again, the case went to the General Assembly, in which all member nations vote, and this time, the member nations voted to approve the notices (INTERPOL 2007b).

The international objections to Vahidi's nomination, which referred to the accusations that had landed him on the list, as well as his status as a man "wanted by Interpol" (Slackman 2009), were credited with strengthening his credentials with the Iranian parliament and helping the subsequent approval of his candidacy (Sturcke 2009).

Another case was that of Kazakhstan's former prime minister, Akezhan Kazhegeldin, who became an opposition figure to President Nursultan Nazarbayev's government, which has been widely accused of human rights violations (Human Rights Watch 2012; US Department of State 2012); and characterized as a dictatorship (Norman 2011; Stodghill 2006). In 1999, a Red Notice requested by the Kazakh National Bureau resulted in Kazhegeldin's detention in Russia, and then again in 2000 in Italy, although in both instances he was released because the Kazakh general prosecutor failed to produce sufficient evidence. A third attempt, this time with terrorism charges, was caught by the Office of Legal Affairs, which revoked the notice. The revocation was upheld by a unanimous Executive Committee. Upon appeal in 2002, however, the General Assembly gave its approval, and the Red Notice was sent out and posted on the Interpol website, where it remains (Savino 2010, 48).

By the standards of Interpol's Office of Legal Affairs, and Executive Committee, the General Assembly made an erroneous decision about Kazhegeldin. No reasons were given for the vote against Interpol's own legal judgment (INTERPOL 2002), although Nazarbayev, who wields power over considerable energy resources in a country seen as a necessary partner for economic and regional stability, and against Islamic extremism (Nichol 2012), enjoys favor among powerful politicians in many nations (Stodghill 2006). The outcome suggests that representatives, charged with advancing the law enforcement interests of their own nations, cannot consistently constitute an apolitical neutral body. Yet the final determination about whether a Red Notice will be issued rests with the majority vote of the General Assembly.

Although the Red Notice is not formally binding, simply being the 
subject of a red notice can deprive individuals of freedom of movement, result in detention, or imprisonment. Countries will often make a provisional detention or arrest and then evaluate the evidence, as Russia and Italy did for Kazhegeldin (Savino 2010, 7).$^{10}$ The assumption of due process is inherent to Notice procedures, following from the requirement that an authorized judicial body must issue a warrant for arrest. Interpol cannot assess, however, if the warrant was issued in good faith, and if judicial body itself is apolitical.

This combination of elements has not gone unnoticed. The partisan nature of the General Assembly, which is entitled to the last word on red notices; the de facto power of a notice to affect individual liberty; and the intentional limits on Interpol's ability to assess the validity of the accusation or the legitimacy of the accusing body - can have significant consequences for the cases Interpol handles. How these issues are dealt with will denote trends in the active development of procedures for responsibility and accountability in international governance. ${ }^{11}$

\section{Wither Sovereignty?}

"Wither sovereignty" declared a blog post in late 2009 on ThreatsWatch, the online presence of the "Center for Threat Awareness" (Schippert and Middleton 2009). ${ }^{12}$ The title made the needling suggestion that the authority of the United States to govern itself was shriveling away. The blog reported that President Obama had authorized Interpol, a nonAmerican law enforcement agency, to investigate and arrest citizens, while at the same time making their archives inviolable, thus exempting them from subpoe- nas, Freedom of Information Act requests, or access to their offices by American law enforcement. This would of course hold dark implications for citizens, but the deeper conspiracy was that this was the first step of a plot by President Obama to prosecute officials from the prior Bush administration for war crimes, ultimately with an eye to turning them over to the International Criminal Court in The Hague.

The story was picked up by Newt Gringrich, who shared it with a much wider audience in a January 4th 2010 television appearance on Fox News' The O'Reilly Factor.

The president recently signed very quietly an executive order that basically releases Interpol from all American constraints. Freedom of Information Acts don't apply. All the constraints that you as a citizen could use against an American police force, based on a recent Obamasigned executive order, give Interpol, which has relationships with Syria, with Libya, with Iran ... What I'm told is that it could lead to a number of investigations by Interpol in the United States, potentially aimed at American officials. 
Outrage spread rapidly in an online and print community that is characterized by the way it finds evidence of conspiracy against America (the nation, rather than the government). Horrified commentators ranging from film and TV star Chuck Norris to lawyer and conservative columnist Andy McCarthy at the National Review exhorted the American public to pay attention, to protest that the president had signed away significant elements of US sovereignty, and the rights of citizens were in danger. However fantastic their assumptions about what the Executive Order meant-indeed, these were completely removed from reality-both in their fantastical nature and in foregrounding the issue of sovereignty, they were representative of the suspicions with which Interpol has been regarded.

The executive order in question (Obama 2009), signed on December 16, 2009, was actually an amendment to President Ronald Reagan's 1983 Executive Order 12425 (Reagan 1983). Reagan's order was issued in order for Interpol to hold its 1985 General Assembly meeting in New York (Billington 2010). Throughout the mid-twentieth century, FBI Director J. Edgar Hoover had jealously restricted American involvement in Interpol. After his death in 1972-and in the wake of increased terrorism in the 1970s, and Interpol's help in extraditing alleged terrorists - the United States began increasing its Interpol staffing and financial contributions. Reagan designated Interpol a public international organization under the International Organizations Immunities Act (IOIA) so that the meeting could be organized and held on US soil, but withheld certain privileges. The reasons for the limitations in Reagan's order at the time were uncomplicated:

Since Interpol does not have an office or staff in the United States, and there- fore has no property, assets, archives, or permanent employees located in the United States, several of the specific privileges, exemptions and immunities available under the IOIA may be inapplicable or irrelevant to Interpol.

Noble (2010)

President Clinton removed the restrictions on one clause related to taxes in 1995 (Clinton 1995); no one paid any attention. Obama removed the rest of the restrictions, so that Interpol was fully possessed of the rights of an international organization in the United States. Obama took this step because Interpol had opened a new office in New York in order to collaborate with the United Nations. Despite ThreatsWatch claims, the status of "international organization" applied only to the New York office, not to the National Central Bureau housed in the Washington, DC, 
Department of Justice (Billington 2010). "[T]he executive order gives Interpol no law- enforcement or investigative powers to engage in activities on U.S. soil," the Secretary General of Interpol wrote in a January 2010 Op-Ed in Newsweek aimed at countering the conspiracy outrage, such as "searches, seizures or arrests in the U.S." Politifact, a fact-checking project by the Florida-based St. Petersburg Times, provided a point-by-point rebuttal (2010).

Interpol doesn't have police powers to abuse. It can't arrest anyone, and it doesn't conduct investigations. And even if it did, the organization's con- stitution bounds it to operate "within the limits of the laws existing in the different countries." The only relevant law Obama's executive order waives covers search and seizure, and that right can be reclaimed if the president deems it necessary.

Analyses that came to the same conclusion were produced on all sides, from the National Rifle Association (2010) to The New York Times (Savage 2009) but were rejected by Gringrich and his ilk. The Secretary General's explanatory editorial in Newsweek was also ignored or dismissed by those intent on finding a conspiracy.

Their outrage, however misplaced in this instance, is revealing. The idea of "police" implicit in the 2010 uproar over the executive order is that of an instrument of a sovereign state (Foucault 2008, 1-25). The intrusion of what were presumed to be Interpol's police powers was therefore taken as a direct affront to national sovereignty. In practice, a nation's police powers of surveillance or detention or arrest usually cross borders by means of a bilateral treaty, and are carried out by the police of another nation. The relationship is inter-national, between the two parties. Less frequently Interpol acts as one party, when treaties do not exist or while the person's location is unknown, for example. In a bricolage typical of global policing, notices can be thought of as legally "parasitic," in that they draw their force from other legal texts, including bilateral agreements, domestic law criminalizing an act for which someone is sought, extradition treaties, or occasionally international human rights law (Savino 2010, 41).

Interpol, however, has neither the powers nor the objective of sovereignty over the collected member nations. Rather, its commitment is to "collective security" (Noble 2009a). This is a rhetorical framing which nonetheless can be understood as a form of action which emerges from the complex objects and subjects that constitute Interpol. Global policing works through a combination of technologies (databases, meetings, Notices, etc.) to cross national boundaries, and requires "the possibility of movement, change of place, and processes of circulation of both people and things" (Foucault 2007, 71). The diverse elements through which it 
produces its version of "collective security" are not made exceptional (Waever 1995) or an organizing principle of everyday life (Bajc 2011), but they are linked together, preserving their diversity and motion.

\section{"Violent Crime Commonly referred to as Terrorism"}

When a plane from Czechoslovakia was hijacked in 1951 and landed on a US airbase in West Germany, Interpol issued Red Notices on behalf of the Communist government (Sheptycki 2004). Objecting that the hijack- ing was a political, not criminal act, FBI Director J. Edgar Hoover withdrew US law enforcement from participation in Interpol. At the next General Assembly, a resolution was passed implementing a standard of predominance, which declared that Interpol was restricted by Article 3 of its constitution from assisting with "offenses of a predominantly political, racial or religious character" even if these pertained to common crimes (INTERPOL 1951). This was gradually reinterpreted over the course of the 1970s via resolutions allowing Interpol to cooperate on matters pertaining to hijacking and hostages, which could jeopardize general public safety (Deflem and Maybin 2005). These changes were still not open-ended enough for Interpol to act after the Black September attacks at the Munich Olympics in 1972, despite widespread international opprobrium of the events. In the 1980s, Interpol refused to send Notices or even "clear information about Nazi war criminals due to the perceived 'political' content of this information, and [the sense] that these types of cases ultimately fell outside their area of competence" (Barnett and Coleman 2005, 608).

Interpol risked obsolescence by not assisting member states in their counterterrorism efforts. In recognition of this, in 1984 the organization passed two resolutions that gradually shifted terrorism from a sore point to the central directive it has become within its global mission. The first resolution placed "violent crime commonly referred to as terrorism" within the organization's mandate by linking it to ordinary law crimes. (INTERPOL 1984a). The second, "Application of Article 3 of the Constitution," resolved that while a criminal act would be assessed as predominantly political or not on a case-by-case basis, a violent political act outside a "conflict area" did not count as political, meaning Interpol could likely address "foreign" terrorism in Europe or the United States (INTERPOL 1984b).

In 1998, Interpol issued guidelines and a declaration that, in a further definitional gambit, divided terrorist acts into their criminal components, rather than evaluating the motive or the ends used as justification. The 1998 governance documents built upon something akin to the notion that an act is criminal when it "offends strong and defined states of the 
collective conscience" (Durkheim 1997, 40). Interpol, attempting to appeal to, and even create, such a collective conscience, presented the justification that such acts were a danger "to the State of Law, to democracy, and to human rights" (INTERPOL 1998). When the events of September 11, 2001 took place, Interpol was primed to pass a resolution declaring the acts a "crime against humanity" (INTERPOL 2001). The previous internal prohibition against counterterrorism was wholly inverted as a mandate to participate, justified in the name of Interpol's constitutional directive to act "in the spirit of the 'Universal Declaration of Human Rights" " (INTERPOL 1956; Bassiouni 2002).

Secretary General Noble began his incumbency eager to raise the profile and increase the acting power of the organization under him. Even before 9/11, he had directed Interpol to prepare for "24/7" staffing at headquarters, which was then fortuitously positioned for roll-out, with terrorism as a strategic rationale. At the first post-9/11 assembly, Noble announced reorganization and a proposal for making "the issuance of Red Notices for terrorists the highest priority" (Noble 2001). In 2002, the database for stolen, counterfeit or forged identify documents was launched. ${ }^{13}$ In 2005, the Interpol-UN Security Council Special Notice was created to notify member nations about individuals and entities subject to sanctions imposed by the United Nations Security Council.

In June 2007, UK Prime Minister Gordon Brown directed that terrorism be redefined as a crime problem. "Let us be clear," said home secretary Jacqui Smith, "terrorists are criminals, whose victims come from all walks of life, communities and religions" (Rieff 2007). This distancing from "war on terror" rhetoric, which would occur slightly later in the United States, was not empty, but rather allowed counterterrorism to be aligned with counter-crime police work. For Interpol, it meant a higher profile for the role it was already exercising with its publicly searchable Red Notice gallery and promotion of UN Security Council agreements. Indeed, Interpol's participation in counterterrorism has been successful in two ways. One is in its traditional niche of facilitating others' actions, and in so doing, also shaping them. The other is in providing a forum to display the actions that governments want made public, which even a "wanted notice"-by definition not yet a security success-serves to announce. In contrast, Noble's efforts to create an antiterrorism intelligence task force and flashy operational support such as the Command and Coordination Centre (Noble 2007d, Interpol 2012b) have fallen flat. Interpol cannot be considered an important player in these aspects of counterterrorism; nations may be interested in including Interpol in their arsenals, but not by conceding clandestine forms of action such as intelligence.

As the Heads of NCBs meeting continued, some of the country 
representatives postured and debated; many worked on their computers or phones, or spoke quietly to people seated nearby. Eventually, the bioterrorism program director gave his 15-minute update to the assembly. We passed out the questionnaires, received back a disappointingly small number, and returned to our fortress headquarters.

\section{International and Global Policing}

By providing an interface for information sharing, a venue for publicity, infrastructure support, best practices, and trainings, Interpol alters practices of local, national, and regional policing, and international governance, and, iteratively, its own. Clearly, the effects of Interpol's global policing are not felt everywhere, nor are they homogeneous. They ramify beyond the delimiting feature of knowledge work augmented by techno- logical improvements, and its political-legal framework.

One axis of seemingly inevitable transformation is funding. Interpol has moved to reduce the importance of statutory contributions from member nations by obtaining grants from entities interested in subsidizing specific efforts (Noble 2008). ${ }^{14}$ The organization sought funding from the Sloan Foundation to start a bioterrorism prevention program (Olsiewski 2007). Equipped with $\$ 4,500,000$ (Alfred P. Sloan Foundation 2009, 68), the program provided regional trainings on bioterrorism preparedness, and ran the briefly lived "biocriminalization" project where I worked. Promoting biocriminalization meant that I catalogued laws nations had already drafted and/or passed, criminalizing acts such as the possession, transfer, or transport of "dangerous biological agents and toxins." The project added Interpol to the ranks of NGOs engaged in similar tasks around legal frame- works. The aggregation of laws that criminalize or regulate chemical and nuclear weapons, for example, may eventually mean, in a patchwork but effective fashion, that there are "global" crimes. The largest single funding block to Interpol to date, however, has been from the international governing body of football (soccer), FIFA, with a donation of US\$20 million to counter match-fixing (Interpol 2012b). The final total for a cybercrime complex in Singapore, still under construction, will presumably be higher. As Interpol diversifies its financing beyond statutory member dues (Noble 2011), the ability to influence its activities will increase.

Other forms of police action and cooperation are of course shaping and contributing to global policing. Europol, for example, has been engaged in the unprecedented development of transnational policing with some supranational authority. ${ }^{15}$ Law enforcement agencies such as the New York Police Department and the US Department of Justice's FBI and Drug Enforcement Administration (DEA), use a widespread system of 
liaison officers (Wirtz and Sullivan 2009). United Nations Police, which are member nation units deployed for the UN, are active in conflict areas, and often have the right to use force (United Nations 2013). When first dispatched in the $1960 \mathrm{~s}$, their powers were extremely limited, but since 2000 they have a mandate to reform and restructure local police forces, in addition to advisory, training, and monitoring tasks. ${ }^{16}$

Table 9.1 lays out schematically the distinctions described in the previous sections, between international and global policing as carried out by Interpol. Cooperative investigations, stings, and manhunts, enacted through bilateral agreements directly between countries (Gerspacher 2008, 181), still formalize and facilitate the majority of police operations involving crimes across borders, or crimes committed in more than one country, such as drug trafficking from producer country to consumer. The well-established practices of international policing have provided crucial elements for the less settled assemblage of global policing. Global policing enables and is complementary to the stable processes of cooperation.

Table 9.1 Comparison of International and Global Policing at Interpol

\begin{tabular}{|c|c|c|}
\hline $\begin{array}{l}\text { Mode of police } \\
\text { cooperation }\end{array}$ & $\begin{array}{l}\text { International policing (traditional } \\
\text { Interpol) }\end{array}$ & Global policing (“New Interpol”) \\
\hline $\begin{array}{l}\text { Conditions of } \\
\text { emergence }\end{array}$ & $\begin{array}{l}\text { Early 1900s, largely "high/politicized" } \\
\text { policing of anarchist movement; } \\
\text { protection of elites' interests (thieves and } \\
\text { swindlers at Monaco casinos, theft of } \\
\text { Austrian jewels recovered in France) }\end{array}$ & $\begin{array}{l}\text { Return of politicized policing with } \\
\text { increased pressure from al-Qaeda } \\
\text { terrorist network } 1990 \text { onward, } \\
\text { accelerated after } 9 / 11\end{array}$ \\
\hline \multirow{3}{*}{ Rationale } & $\begin{array}{l}\text { Perception of increasing crime (after } \\
\text { World War II); }\end{array}$ & $\begin{array}{l}\text { Conceptualization of threats as events } \\
\text { that emerge rapidly, unpredictably }\end{array}$ \\
\hline & $\begin{array}{l}\text { Functional differentiation between } \\
\text { internal and external security; }\end{array}$ & $\begin{array}{l}\text { Neither threats nor security are } \\
\text { territorially bound }\end{array}$ \\
\hline & $\begin{array}{l}\text { Cold War; } \\
\text { Crime as issue of national security } \\
\text { (transnational organized crime) }\end{array}$ & $\begin{array}{l}\text { Terrorism as a crime, the global pursuit } \\
\text { of which is made public by } \\
\text { governments in order to show their } \\
\text { effort }\end{array}$ \\
\hline Actors & $\begin{array}{l}\text { Seconded officers who do work that may } \\
\text { be unrelated to their expertise; lawyers }\end{array}$ & $\begin{array}{l}\text { Permanent staff (lawyers, officers) with } \\
\text { expertise in a crime area (environment, } \\
\text { human trafficking, etc.), in specialized } \\
\text { units }\end{array}$ \\
\hline Form & $\begin{array}{l}\text { A network of connections between equal } \\
\text { nodes: country NCBs; the unit is the } \\
\text { nation }\end{array}$ & $\begin{array}{l}\text { A flexible assemblage of heterogeneous } \\
\text { elements - for some of which the unit is } \\
\text { the nation, for others not }\end{array}$ \\
\hline Purpose & $\begin{array}{l}\text { Maximize efficient police response to } \\
\text { crimes and pursuit of perpetrators }\end{array}$ & $\begin{array}{l}\text { Use information on circulating people } \\
\text { and things to increase preparedness for } \\
\text { crimes and other potential events }\end{array}$ \\
\hline
\end{tabular}




\begin{tabular}{|c|c|c|}
\hline Threat & $\begin{array}{l}\text { Common crimes } \\
\text { Complex criminal conspiracies } \\
\text { Corruption, economic crime, drug } \\
\text { trafficking, organized crime }\end{array}$ & $\begin{array}{l}\text { Complex criminal conspiracies that } \\
\text { threaten the state/are seen as state } \\
\text { concerns } \\
\text { Shared existential and/or moral threats: } \\
\text { terrorism, environmental crimes, human } \\
\text { trafficking, child pornography }\end{array}$ \\
\hline Technologies & $\begin{array}{l}\text { Notice system } \\
\text { Messages concerning criminals and } \\
\text { crime } \\
\text { Standardized in categories red, blue, etc. } \\
\text { "administration of communication } \\
\text { systems" }\end{array}$ & $\begin{array}{l}\text { Data exchange systems and technical } \\
\text { support (e.g. I-24/7, mind and find) } \\
\text { Operational support (e.g. Incident } \\
\text { Response Teams) } \\
\text { Police training and development }\end{array}$ \\
\hline $\begin{array}{l}\text { Target of } \\
\text { interaction }\end{array}$ & $\begin{array}{l}\text { Suspects, perpetrators, those wanted for } \\
\text { crimes, fugitives: individuals }\end{array}$ & $\begin{array}{l}\text { Networks (of terrorists, human } \\
\text { traffickers, drugs) } \\
\text { Pre-crime (proven involvement in } \\
\text { terrorist group, although mere } \\
\text { association with a political group is } \\
\text { insufficient) }\end{array}$ \\
\hline Ethical metric & $\begin{array}{l}\text { Professional cooperation } \\
\text { National interests/individual rights } \\
\begin{array}{l}\text { Dual/double criminality (mutual } \\
\text { recognition between nations of an } \\
\text { offense) }\end{array}\end{array}$ & $\begin{array}{l}\text { Human rights } \\
\text { Universal humanity, standards }\end{array}$ \\
\hline Funding & Statutory contributions & $\begin{array}{l}\text { Targeted contributions from countries } \\
\text { and organizations toward specific goals; } \\
\text { grants }\end{array}$ \\
\hline
\end{tabular}

Stalcup, M. Interpol and the Emergence of Global Policing. (2013) Policing and Contemporary Governance: The Anthropology of Police in Practice. ed. William Garriott, New York: Palgrave MacMillan.

International and intergovernmental organizations have nearimmunity from prosecution, in order that neither a state nor an individual can cripple its action. However, as organizations such as Interpol produce what is increasingly considered global governance, through their acts, or by providing the means for action with determinative repercussions for local life, courts have become more willing to hear cases against them (Cheah 2012, 378-380). Remedial bodies have been established by Europol, the UN Security Council, and Interpol, in order to preemptively foreclose lawsuits by offering an alternative course of action for individuals with a grievance. Wui Ling Cheah suggests that this represents the process of legalization, narrowly defined as a specific form of institutionalization and self-governance featuring "the adoption of rules that are legally binding, precise and enforceable through dispute 
resolution before independent third-parties" (Abbot et al. 2000; Cheah 2010, 33). For Interpol, this independent remedial body is the Commission for the Control of Interpol's Files (CCF). Together with the messier discussions in annual meetings, regional conferences, legal evaluation of notices and diffusions, and press releases, the Commission now plays a distinct role in Interpol's self-governance practices. However, the CCF can ultimately only advise. Decision-making power (about access to files or Notices) rests with the General Secretariat, and ultimately with the General Assembly. ${ }^{17}$

Marion Fourcade comments that it is "one thing to point to transnational institutions, communities, and actors and to show that they generate distinctive outcomes (e.g., the diffusion of norms about human rights or economic policies). It is quite another to show how their very existence relates to broader patterns of social and economic transformation" (2006, 152). The development of Interpol's position on terrorism and its role in countering it, for example, were part of a post9/11 bandwagon, yet global policing, although it advanced by these means, cannot be reduced to it. Terrorism served as a strong justification for change in the organization; however, the way that Interpol redefined terrorism as well as how it redefined itself in relation to clusters of issues has resonance with other global phenomena in the world today. As McKeon noted, "We have not had much practice on a world scale in the kind of cooperation that substitutes confidence in ideas as expressions of reasons for suspicion of ideas as cloaks for unexpressed reasons underlying proposed action" (1948a, 578). In as much as global policing has proceeded through the development of policies, protocols, and shared practices-and at Interpol this has been the primary mode of development-it seems no closer to settling for member constituencies how to resolve philosophical differences (on human rights, crime, or terrorism); yet it does present an instructive case in which a political frame has been sought for common action.

\section{Notes}

1. According to the Interpol press office, recent speeches and comments by the Secretary General, "can be seen as official statements of INTERPOL policy" and will be treated as such in this chapter. See http://www.interpol.int/News-and-media/Media-room/Information-forjournalists, accessed 4 May 2013.

2. Interpol began electronic record-keeping in 1972 (Cheah 2012, 386) but used Morse Code to communicate until the latter half of the 1980s, when it switched to email (Sheptycki 2004, 116).

3. Similarly, Wirtz and Sullivan distinguish between international policing 
and "global metropolitan policing" (2009). "In international policing," they write, "national police organizations served as the conduit for sharing information among foreign law enforcement agencies." In global metropolitan policing, "local police forces are developing and sharing expert 'systems of knowledge' with fellow professionals across national boundaries," which can include "national and metropolitan law enforcement agencies as well as linkages with intelligence organizations, non-governmental organizations, and private and corporate security entities." They exclude Interpol from this "metropolitan" version of global policing, however, whereas I argue that Interpol is better viewed as a significant embodiment of global policing, shaping in specific ways even the metropolitan elements.

4. In the terminology I use, Interpol is part of the global policing assemblage, which is more dynamic (less settled and stable) than the overall global police cooperation apparatus. See Rabinow $(2003,54-56)$ for an in-depth differentiation of apparatuses and assemblages.

5. On that history, in addition to those references listed in this text, see Deflem (2002); Fooner (1989); Gerspacher (2008); Nadelmann (1993).

6. Finnemore and Troope $(2001,749)$ describe legitimacy in law as deriving from a number of interrelated sources, including "attention to internal legal values." They add, "law is legitimate only to the extent that it produces rules that are generally applicable, exhibit clarity or determinacy, are coherent with other rules, are publicized (so that people know what they are), seek to avoid retroactivity, are relatively constant over time, are possible to perform, and are congruent with official action." Arguably, although lacking a treaty, Interpol has attempted legitimacy by treating its founding documents along these same lines.

7. In the United States, for example, in 1938 and then again in 1958, Congress authorized the Attorney General to accept and maintain membership, along with dues payable to Interpol (22 U.S.C. 263). See Schermers, HG and Blokker, NM, International Institutional Law: Unity within Diversity. Boston, Martinus Nijhoff Publishers (2003) para 36, cited in Martha (2010), 194.

8. The UN Secretariat seems to leave itself some room to maneuver if challenged, in that its acceptance of an instrument for registration does not confer "the status of a treaty or international agreement if it does not already possess that status" (Michel 2011). Interpol refers to itself, however, as an "intergovernmental organization" (INTERPOL 2010c).

9. In addition, see the Fair Trials International, which lists Shahram Homayoun, Rasoul Mazrae, Ilya Katsnelson, and Akezhan Kazhegeldin, among others.

10. See Savino's 2010 article for a much more in-depth accounting of the implications of Interpol's Red Notices. Additionally, nations will sometimes provisionally detain an individual on a Diffusion, or when a notice only requested information (such as a Blue Notice to locate/identify a person of interest in a criminal investigation). 
11. See, for example, the Institute for International Law and Justice at New York University School of Law http://www.iilj.org/GAL/.

12. The Center for Threats Awareness is a think tank with 501(c)3 tax-exempt status.

13. Convincing countries to fill that database remains a challenge; see Noble (2007d).

14. For information on Interpol's finances, see Interpol (2012b, 51): "For the financial year 2011, INTERPOL's operating income totaled EUR 60 million, of which $84 \%$ was contributed by member countries, mostly in the form of statutory contributions $(83 \%)$. Income received on externally funded projects or from private foundations and/or commercial enterprises with similar objectives or interests to INTERPOL constituted $13 \%$ of gross income. Other income and reimbursements made up $3 \%$ of the total."

15. There is a large body of literature concerning Europol, its unique development, and special status. See, for example, Deflem (2010); Fijnaut (1992); Gerspacher (2005, 2010); Marenin (2005); and Pocar (2004).

16. Alice Hills suggests that the problem with UN police is that "efficient policing" means very different things in different places. Normative proposals for a global "constabulary ethic" (Sheptycki 2010) seem to assume that "effective and democratic policing are synonymous" (Hills $2009,304)$, when in fact efficient policing can mean the violent perpetuation of a non-democratic and repressive regime. Hills argues that, although a subset of the policing literature may assume that police officers "share a distinctive outlook in the world," constituted by "a set of assumptions, values, modes of thinking and acting," or a "consensus on what is necessary for effective policing," there is not yet an "operationally meaningful transnational policecraft" (ibid.). Regardless, Interpol, in that it is not a police force, would seem unlikely to share that craft or ethic, despite its own rhetoric.

17. Under Article 18 of the Rules on the Processing of Data, individuals do have the right to request access to the information concerning them processed by Interpol (2012a, 12) but by those same rules (Article 135), regardless of what the independent advisory Commission for the Control of Interpol's Files advises, the final decision has to be taken by the General Assembly.

\section{Reference List}

Alfred P. Sloan Foundation. Alfred P. Sloan Foundation: A Grantmaking History 1934-2009. 2009. New York: Alfred P. Sloan Foundation.

Abiad, Pablo. 2006. "Indagatoria al ex jefe de la SIDE en la causa por irregularidades en el caso AMIA." Diario Clarín, 24 June. http://www.clarin.com/diario/2006/06/24/elpais/p-01401.htm, accessed 21 May 2010.

AFP. 2010. "Interpol Approves New Hi-Tech Crime Centre in Singapore." Google News, 9

November. http://www.google.com/hostednews/afp/article/ALeqM5juVhJv8klgNWyZN3jAOgpXjIOHw?docId=CNG.3cf470a7cf4347e0adfc867209ed1589.1d1, accessed 10 February 2012. 
Bajc, Vida. 2011. "Security Meta-Framing: A Cultural Logic of an Ordering Practice." In Security and Everyday Life, edited by V. Bajc and W. d. Lint. New York and Oxford: Routledge. Barnett, Michael and Liv Coleman. 2005. "Designing Police: Interpol and the Study of Change in International Organizations.” International Studies Quarterly 49 (4):593-620. Bassiouni, M. Cherif. 2002. "Legal Control of International Terrorism: A Policy-Oriented Assessment." Harvard International Law Journal 43 (1):83-103.

BBC News. 2006. "Iran Charged over Argentina Bomb." 25 October. http://news.bbc.co.uk/2/hi/americas/6085768.stm, accessed 22 May 2010.

- - - 2009. "Iran minister on Interpol List." 21 August. http://news.bbc.co.uk/go/pr/fr//2/hi/middle_east/8215293.stm, accessed 21 May 2010

Berri, Jorge Urien. 2006. "Rodolfo Canicoba Corral: el juez que desafía a Teherán." La Nación, 19 November. http://www.lanacion.com.ar/859818-rodolfo-canicoba-corral-el-juez-que-desafiaa-tehera, accessed 18 February 2011.

Billington, Rachael (Interpol Press Officer). 2010. e-mail message to the author, May 18. Bowling, Ben, and James Sheptycki. 2012. Global Policing. Thousand Oaks, CA: Sage.

Brodeur, Jean-Paul. 1983. "High Policing and Low Policing: Remarks about the Policing of Political Activities." Social Problems 30 (5):507-520.

Center for Threat Awareness-Think tank 2.0 ${ }^{T M}$. http://threatswatch.org, accessed 23 May 2010. Cheah, Wui Ling. 2010. "Mapping Interpol's Evolution: Functional Expansion and the Move to Legalization." Policing 4 (1):28-37.

- - - 2012. "Policing Interpol: The Commission for the Control of Interpol's Files and the Right to a Remedy.” International Organizations Law Review 7 (2):375-404.

CITES. 2011. "CITES Secretary-General praises Project Predator." Convention on International Trade in Endangered Species of Wild Fauna and Flora, 28 November.

http://www .cites.org/eng/news/press/2011/20111128_predator.php, accessed 4 February 2012.

Clinton, William J. 1995. “Amendment to Executive Order No. 12425. Executive Order 12971

of September 15, 1995.” 60 C.F.R 48617. http://www .gpo.gov/fdsys/pkg/FR-1995-09-

19/pdf/95-23423.pdf, accessed 22 May 2010.

Cockayne, James. 2007. "Transnational Organized Crime: Multilateral Responses to a Rising

Threat." Coping with Crisis Working Paper Series. http://ssrn.com/paper=1008168, accessed 11 October 2010

Collier, Stephan J., and Aihwa Ong. 2004. "Global Assemblages, Anthropological Problems.” In Global Assemblages: Technology, Politics, and Ethics as Anthropological Problems, edited by

A. Ong and S. J. Collier. London: Blackwell.

Deflem, Mathieu. 2002. Policing World Society: Historical Foundations of International Police Cooperation, Clarendon Studies in Criminology. Oxford: Oxford University Press.

- - - 2010. The Policing of Terrorism: Organizational and Global Perspectives. New York and Oxon: Routledge.

Deflem, Mathieu and Lindsay C. Maybin. 2005. "Interpol and the Policing of International Terrorism: Developments and Dynamics since September 11." In Terrorism: Research, Readings, \& Realities, edited by L. L. Snowden and B. Whitsel. Upper Saddle River, NJ: Pearson Prentice Hall.

Durkheim, Emile. 1997 (1933). The division of labor in society. Translated by W.D. Halls. New York: Free Press.

Fair Trials International. 2011. Interpol: Cases of Injustice. London: Fair Trials International. 
Foucault, Michel. 2007. Security, Territory, Population: Lectures at the Collège de France 1977-78. Translated by G. Burchell. New York and Basingstoke: Palgrave Macmillan.

- - - 2008. The Birth of Biopolitics: Lectures at the Collège de France 1978-79. Translated

by G. Burchell. New York and Basingstoke: Palgrave Macmillan.

Fijnaut, Cyrille. 1992. "Policing Western Europe: Interpol, Trevi and Europol." Police Studies 15 (3):101-106

Finnemore, Martha J. and Stephen Toope. 2001. “Alternatives to 'Legalization': Richer Views of Law and Politics.” International Organization 55 (03):743-758.

Fooner, Michael. 1989. Interpol: Issues in World Crime and International Criminal Justice.

New York: Plenum Press.

Fourcade, Marion. 2006. "The Construction of a Global Profession: The Transnationalization of Economics." American Journal of Sociology 112 (1):145-94.

Gerspacher, Nadia. 2005. "The Roles of International Police Cooperation Organizations-Beyond Mandates, toward Unintended Roles." European journal of crime, criminal law and criminal justice 13 (3):413-434.

- - - 2008. "The History of International Police Cooperation: a 150-year Evolution in Trends and Approaches." Global Crime 9 (1 \& 2):169-184.

Gerspacher, Nadia and Veronique Pujas. 2010. "International Police Organizations: The Missing Link to Effective Cooperation." In International Police Cooperation: Emerging Issues, Theory

and Practice, edited by F. Lemieux. Cullompton and Portland: Willan Publishing.

Gingrich, Newt. 2010. "Newt Gingrich speaks out on INTERPOL.wmv." YouTube video, 8:02, from appearance on The O'Reilly Factor televised by Fox News on 4 January 2010, posted by "tcald52," 4 January 2010. http://www.youtube.com/watch?v=bbR2m_Tjpfk, accessed 16 May 2010.

Hills, Alice. 2009. “The Possibility of Transnational Policing.” Policing and Society: An International Journal of Research and Policy 19 (3):300-317.

Human Rights Watch. 2012. "Human Rights in Kazakhstan." http://www.hrw.org/europecentralasia/kazakhstan, accessed 8 September 2012.

INTERPOL. 1951. "Request for International Inquiries Resolution No. AGN/20/RES/11."

Lisbon: INTERPOL.

https://secure.interpol.int/Public/ICPO/GeneralAssembly/AGN20/Resolutions/AGN20RES11.as p, accessed 04 May 2013.

- - _ 1956. "ICPO-INTERPOL Constitution and General Regulations."

https://secure.interpol.int/Public/ICPO/LegalMaterials/constitution/constitutionGenReg/constitut ion.asp, accessed 04 May 2013.

- - - . 1984a. "Violent Crime Commonly Referred to as Terrorism Resolution No.

AGN/53/RES/6.” Luxembourg: INTERPOL.

https://secure.interpol.int/Public/ICPO/GeneralAssembly/AGN53/Resolutions/AGN53RES6.asp

, accessed 4 May 2013.

- - . 1984b. "Application of Article 3 of the Constitution Resolution No. AGN/53/RES/7."

Luxembourg: INTERPOL. http://www.interpol.int/Media/Files/General-

Assembly/Resolutions/1984/AGN-1984-RES-7-Application-of-Article-3-of-the-constitution, accessed 4 May 2013.

- - . 1998. "Cairo Declaration Against Terrorism Resolution No AGN/67/RES/12 1998."

Cairo: INTERPOL. http://www.interpol.int/Media/Files/General- 
Assembly/Resolutions/1998/AGN-1998-RES-12-Cairo-declaration-against-terrorism, accessed 4 May 2013.

- - - 2001. "Terrorist Attack of 11 September 2001 Resolution No AG-2001-RES-05.”

Budapest: INTERPOL.

https://secure.interpol.int/Public/ICPO/GeneralAssembly/AGN70/Resolutions/AGN70RES5.asp , accessed 4 May 2013

- - . 2002. "INTERPOL re-issue of red notice on former Kazakhstan PM."

http://www.interpol.int/en/Internet/News-and-media/News-media-releases/2002/PR031, accessed 8 September 2012

- - - 2005. "Argentinean Red Notices for Iranian Officials Cancelled."

http://www.interpol.int/News-and-media/News-media-releases/2005/PR041, accessed 8

September 2012.

- - - 2007a. "INTERPOL Executive Committee takes decision on AMIA Red Notice dispute." http://www.interpol.int/News-and-media/News-media-releases/2007/PR005, accessed 22 May 2010

- - - . 2007b. "INTERPOL General Assembly upholds Executive Committee decision on AMIA Red Notice dispute.” http://www.interpol.int/News-and-media/News-mediareleases/2007/PR054, accessed 22 May 2010.

- - . 2010a. 2000-2010 INTERPOL Fighting 21st Century Crime. Lyon: INTERPOL. -- - 2010b. "NCB Doha in the Spotlight."

https://secure.interpol.int/Public/ICPO/GeneralAssembly/Agn79/NCBDoha.pdf, accessed 4 May 2013.

- - - .2010c. “About INTERPOL.” Last updated 28 November 2012.

https://secure.interpol.int/public/icpo/default.asp, accessed 4 May 2013

- - - 2011. "AG-2011-RES-15 Registration of INTERPOL's Constitution under Article 102 of the United Nations Charter."

http://www.interpol.int/content/download/12493/86010/version/5/file/AG-2011-RES-15.pdf, accessed 4 May 2013.

- - . 2012a. INTERPOL's Rules on the Processing of Data. Lyon: INTERPOL.

- - - . 2012b. Interpol Annual Report 2011. Lyon: INTERPOL.

Jensen, Richard Bach. 1981. "The International Anti-Anarchist Conference of 1898 and the

Origins of Interpol. " Journal of Contemporary History 16 (2):323-347.

- - - 2004. "Daggers, Rifles and Dynamite: Anarchist Terrorism in Nineteenth Century

Europe." Terrorism and Political Violence 16 (1):116-153.

Johnston, Ian. 2012. "Interpol Faces Legal Threat for Helping Oppressive Regimes Hunt

Dissidents." msnbc.com, 23 January.

http://worldnews.msnbc.msn.com/_news/2012/01/23/10167327-interpol-faces-legal-threat-forhelping-oppressive-regimes-hunt-dissidents, accessed 15 February 2012.

Kapferer, Bruce. 2005. "New Formations of Power, the Oligarchic- Corporate State, and Anthropological Ideological Discourse.” Anthropological Theory 5 (3):285-299.

Khoo, Boon Hui. 2009. "5th Heads of NCBs Conference Keynote Speech." https://secure.interpol.int/Public/ICPO/speeches/2009/5thHeadsNCBPresident20090303.asp, accessed 4 May 2012.

Liang, Hsi-Huey. 1992. The Rise of Modern Police and the European State System from Metternich to the Second World War. New York: Cambridge University Press. 
Lemieux, Frédéric. 2010. “The Nature and Structure of International Cooperation: An Introduction." In International Police Cooperation: Emerging Issues, Theory and Practice, edited by F. Lemieux. Cullompton and Portland: Willan Publishing.

Lewis, Libby. 2011. "Interpol's Red Notices Used by Some to Pursue Political Dissenters, Opponents." iWatch News, 18 July. Last Updated 11 January 2012.

http://www.iwatchnews.org/2011/07/18/5179/interpols-red-notices-used-some-pursue-politicaldissenters-opponents, accessed 1 March 2012

Marenin, O. 2005. "Building a global police studies community." Police Quarterly 8 (1):99-136. doi: $10.1177 / 1098611104267329$.

Martha, Rutsel Silvestre J. 2010. The Legal Foundations of INTERPOL. Oxford and Portland, OR: Hart Publishing.

McKeon, Richard. 1948a. "A Philosophy for UNESCO.” Philosophy and Phenomenological Research 8 (4):573-586.

- - - 1948b. "The Philosophic Bases and Material Circumstances of the Right of Man."

Ethics 58 (3):180-187.

- - - 1990 (1970). Philosophy and History in the Development of Human Rights. In Freedom and History and Other Essays: An Introduction to the Through of Richard McKeon, edited by Z. K. McKeon. Chicago and London: University of Chicago.

Michel, Nicholas. 2011. 'Letter of the United Nations' Under-Secretary General for Legal Affairs Dated May 6, 2008." Appendix 1, AG-2011-RES-15. Hanoi: INTERPOL

Naím, Moisés, and Raymond Kendall. 2001. "The FP Interview: Meet the World's Top Cop." Foreign Policy 122 (Jan-Feb):31-40.

National Rifle Association of America (NRA). 2010. "INTERPOL Rumors.” National Rifle Association of America Institute for Legislative Action, 8 January.

http://www.nraila.org/legislation/read.aspx?id=5284, accessed 4 may 2013

Nichol, Jim. 2012. Kazakhstan: Recent Developments and U.S. Interests. Washington DC:

Congressional Research Service.

Noble, Ronald K. 2001. "70th INTERPOL General Assembly 24-28 September 2001 Speech." https://secure.interpol.int/Public/ICPO/speeches/20010924.asp, accessed 4 May 2013.

- - . 2002. "Connecting the Police, Securing the world."

https://secure.interpol.int/Public/ICPO/speeches/SG20021021.asp, accessed 4 May 2013

- - - .2007a. "Interpol follows the rules." Washington Times, 23 January.

http://www.washingtontimes.com/news/2007/jan/23/20070123-101927-5118r/, accessed 22 May 2010.

- - - . 2007b. "Open letter from INTERPOL Secretary General.” Interpol, 8 July

http://www.interpol.int/News-and-media/News-media-releases/2007/N20070708, accessed 4

May 2013

- - - .2007c. "19th Americas Regional Conference Bogota, Colombia, 25-27 September

2007 Opening speech by Ronald K. Noble Secretary General ICPO-INTERPOL."

https://secure.interpol.int/Public/ICPO/speeches/SGColombia20072509.asp, accessed 4 May 2013

- - - 2007d. "A New Antiterror Strategy." New York Times, 3 July. http://www.nytimes.com/2007/07/03/opinion/03iht-ednoble.2.6468214.html?_r=0, accessed 4 May 2013.

- - - 2008. "4th Annual Heads of NCBs Meeting Lyon, France, 2 April 2008 Opening speech by Ronald K. Noble.” 
https://secure.interpol.int/Public/ICPO/speeches/2008/SGNCBsConf20080402.asp, accessed 4 May 2013.

- - - 2009. "The Other Global Crisis: Dangerous International Criminals Traveling the World." https://secure.interpol.int/Public/ICPO/speeches/2009/5thHeadsNCBsSG20090303.asp, accessed 4 May 2013. - - - 2010. "Misinformation Hurts National Security." Newsweek, 22 January. http://www.newsweek.com/id/231959, accessed 8 November 2010.

- - - 2011. "80th INTERPOL General Assembly Remarks by Ronald K.Noble." https://secure.interpol.int/Public/ICPO/speeches/2011/GA80SgOpening.pdf, accessed 4 May 2013.

Norman, Joshua. 2011. "The World's Enduring Dictators: Nursultan A. Nazarbayev.” CBS News, May 30. http://www.cbsnews.com/8301-503543_162-20067252-503543.html, accessed 7 September 2012.

Obama, Barack. 2009. “Amending Executive Order 12425 Designating Interpol as a Public International Organization Entitled to Enjoy Certain Privileges, Exemptions, and Immunities. Executive Order 13524 of December 16, 2009." http://www.whitehouse.gov/the-pressoffice/executive-order-amending-executive-order-12425, accessed 4 May 2013.

Olsiewski, Paula J. (Program Director, Sloan Foundation). 2007. Interview with the author, 16 October. New York.

Pocar, Fausto. 2004. "New challenges for international rules against cyber-crime." European Journal on Criminal Policy and Research 10 (1):27-37.

Politifact.com. 2010. "Gingrich Claims Obama's Order will Let Interpol Investigate American Officials.” Tampa Bay Times, 4 January. http://www.politifact.com/truth-ometer/statements/2010/jan/12/newt-gingrich/gingrich-claims-interpol-will-investigate-american/, accessed 16 May 2010.

Rabinow, Paul. 2002. "Midst Anthropology's Problems." Cultural Anthropology 17 (2):135149.

- - - 2003. Anthropos Today: Reflections on Modern Equipment. Princeton: Princeton University Press.

Reagan, Ronald. "Executive Order 12425 International Criminal Police Organizations." http://www.presidency.ucsb.edu/ws/?pid=41483, accessed 4 May 2013.

Rieff, David. 2002. A bed for the night: humanitarianism in crisis. New York: Simon \& Schuster.

Russell, Ruth B. 1965. "Changing Patterns of Constitutional Development." International Organization 19 (3):410-425.

Savage, Charlie. 2009. "Order on Interpol Work Inside U.S. Irks Conservatives.” New York Times, 31 December. http://www.nytimes.com/2009/12/31/world/31interpol.html, accessed 16 May 2010.

Savino, Mario. 2010. "Global Administrative Law Meets "Soft" Powers: The Uncomfortable Case of Interpol Red Notices." New York University Journal of International Law and Politics 43 (2):263-336.

Sheptycki, James W. E. 1998. "The Global Cops Cometh: Reflections on Transnationalization, Knowledge Work and Policing Subculture." The British Journal of Sociology 49 (1):57-74. - - - 2000. "Introduction." In Issues in Transnational Policing, edited by J. W. E. Sheptycki. London and New York: Routledge. 
- - - 2004. "The Accountability of Transnational Policing Institutions: The Strange Case of Interpol." Canadian Journal of Law and Society 19:107-134.

Schippert, Steve, and Clyde Middleton. 2009. "Wither Sovereignty: Executive Order Amended to Immunize INTERPOL In America-Is The ICC Next?" ThreatsWatch, 23 December. http://threatswatch.org/analysis/2009/12/wither-sovereignty/, accessed 16 May 2010.

Silver, Allan. 2004 (1967). "The Demand for Order in Civil Society: A review of some themes in the history of urban crime, police and riot." In Policing: Key Readings, edited by T. Newburn. Cullompton and Portland: Willan.

Slackman, Michael. 2009. “Ahmadinejad Nominee Is Wanted in '94 Bombing.” New York Times, 22 August. http://www.nytimes.com/2009/08/22/world/middleeast/22iran.html, accessed 22 May 2010.

Stodghill, Ron. 2006. "Oil, Cash and Corruption.” New York Times, November 5. http://www.nytimes.com/2006/11/05/business/yourmoney/05giffen.html, accessed 8 September 2012.

Sturcke, James. 2009. "Iran Anoints Anti-Jewish Bomb Suspect as Defence Secretary." Guardian, 2 September. http://www.guardian.co.uk/world/2009/sep/02/iran-vahidi-argentinajewish-bombing, accessed 22 May 2010.

Sullivan, Mark P. 2010. Latin America: Terrorism Issues. Washington, D.C.: Congressional Research Service.

Valverde, Mariana and Michael Mopas. 2004. "Insecurity and the dream of targeted governance." In Global Governmentality: Governing International Spaces, edited by W. Larner and W. Walters. London and New York: Routledge.

Waever, Ole. 1995. "Securitization and Desecuritization.” In On Security, edited by R. Lipschutz. New York: Columbia University Press.

Wirtz, James, and John Sullivan. "Global Metropolitan Policing: An Emerging Trend in Intelligence Sharing.” Homeland Security Affairs 5 (2). http://www.hsaj.org/?article=5.2.4, accessed 24 May 2010.

United Nations. 2013. "UN POLICE DIVISION."

http://www.un.org/en/peacekeeping/sites/police/division.shtml, accessed 4 May 2013.

United States Department of State. 2012. "2011 Country Reports on Human Rights Practices: Kazakhstan.” http://www.state.gov/j/drl/rls/hrrpt/humanrightsreport/index.htm?dlid=186466, accessed 4 May 2013. 